\title{
FAKTOR-FAKTOR YANG MEMPENGARUHI PRESTASI AKADEMIK BELAJAR MAHASISWA TINGKAT III DI AKADEMI KEPERAWATAN MANGGALA HUSADA JAKARTA
}

\author{
Suryani Hartati ${ }^{1}$, Ria Anugrahwati 2 \\ 1. Dosen Akademi Keperawatan Manggala Husada \\ 2. Dosen Akademi Keperawatan Manggala Husada
}

E-mail: suryanihartati4@ gmail.com

\begin{abstract}
Abstrak
Prestasi Belajar tidak dapat dipisahkan dari kegiatan belajar, karena belajar merupakan suatu proses, sedangkan prestasi belajar adalah hasil dari proses pembelajaran tersebut. Penelitian ini bertujuan untuk mengetahui faktor faktor apa saja yang dapat mempengaruhi prestasi belajar mahasiswa tingkat III di Akper Manggala Husada. Penelitian ini menggunakan desain survey cross sectional study pada 25 responden mahasiswa khususnya tingkat III. Hasil penelitian berisikan tentang cita-cita, kemampuan belajar, kondisi jasmani dan rohani mahasiswa, kondisi lingkungan kelas, unsur-unsur dinamis belajar, upaya dosen dalam membelajarkan mahasiswa, karakteristik dari 25 responden sebagian besar $(60 \%)$ berjenis kelamin perempuan. Sebagian besar (92\%) responden berusia 15-20 tahun. Faktor yang berpengaruh pada prestasi akademik mahasiswa adalah cita-cita dengan prestasi akademik belajar mahasiswa di Akademi Keperawatan Manggala Husada Jakarta dengan p Value $=0,00$, Nilai $\mathrm{OR}=1,187$ Kali. Rekomendasi dari penelitian ini adalah perlunya bimbingan untuk meningkatkan motivasi dalam proses belajar mengajar untuk mencapai cita -cita
\end{abstract}

Kata kunci: Prestasi belajar, pembelajaran, mahasiswa, cita -cita

\begin{abstract}
Learning Achievement cannot be separated from learning activities, because learning is a process, while learning achievement is the result of the learning process. This study aims to determine what factors can influence the learning achievement of third-level students at Akper manggala Husada. This study uses a cross sectional survey design on 25 student respondents, especially level III. The results of the study consisted of ideals, learning abilities, physical and spiritual conditions of students, classroom environment conditions, dynamic elements of learning, lecturers' efforts to teach students, characteristics of 25 respondents mostly (60\%) female. Most (92\%) of respondents are 15-20 years old. Factors that influence student academic achievement are ideals with academic achievement of student learning at the Manggala Husada Jakarta Nursing Academy with $p$ value = 0.00 , OR value $=1.187$ times. The recommendation of this study is the need for guidance to increase motivation in the teaching and learning process to future goals
\end{abstract}

Keyword: learning achievement, learning, student, future goals 


\section{PENDAHULUAN}

Akademi Keperawatan Manggala Husada memiliki komitmen dalam pengembangan kurikulum KKNI berdasarkan SN Dikti Permenristek Dikti no 44 tahun 2015, kegiatan yang dilakukan seperti mengadakan kuliah pakar, Seminar Internasional, simposium, workshop, dan keterlibatan mahasiswa dalam penelitian dan pengabdian masyarakat dosen. Kegiatan ini dilakukan untuk meningkatkan kualitas pembelajaran yang nantinya akan menghasilkan prestasi akademik bagi mahasiswanya.

Prestasi akademik yang tinggi sangat diperlukan dalam pembelajaran dan sangat berpengaruh terhadap hasil belajar, hal ini memudahkan lulusan untuk mendapatkan suatu pekerjaan, karena syarat diterima di rumah sakit baik pemerintahan maupun swasta indeks prestasi komulatif (IPK) mereka harus atau wajib minimal 2,75 sampai 3.00. Mahasiswa Tingkat III di Akper Manggala Husada berjumlah 25 pada tahun ajaran 2015/2016, sebagian besar mereka mengalami penurunan belajar sehingga prestasi akademik masih dibawah rata rata yang akan mengakibatkan tidak bisanya lulusan bekerja di rumah sakit, oleh karena itu perlu dilakukan penelitian untuk mengetahui factor factor apa saja yang mempengaruhi prestasi belajar mahasiswa.

Prestasi akademik yang tinggi akan meningkatkan hasil belajar (Sukiniarti, 2006), sehingga mahasiswa dipacu untuk mendapatkan nilai IPK sesuai standar dari perguruan tinggi. Prestasi akademik seseorang juga dipengaruhi oleh gaya belajar visual, auditorik, membaca/ menulis yang bisa kita nilai dari kemampuannya secara afektif, kognitif dan psikomotor.Prestasi akademik dapat dipandang sebagai suatu rantai reaksi yang dimulai dari adanya kebutuhan kemudian timbul keinginan untuk memuaskannya (mencapai tujuan) sehingga menimbulkan ketegangan psikologis yang akan mengarahkan perilaku mencapai tujuan yang ingin dicapai oleh seseorang (Pujadi, 2007).

\section{TINJAUAN TEORI}

Prestasi akademik dipandang sebagai dorongan mental yang menggerakkan dan mengarahkan perilaku manusia, termasuk perilaku belajar. Dalam prestasi akademik terkandung adanya keinginan yang mengaktifkan, menggerakkan, menyalurkan dan mengarahkan sikap serta perilaku pada individu belajar (Koeswara, 1989; Siagia, 1989; Sehein, 1991; Biggs dan Tefler, 1987 dalam Dimyati dan Mudjiono, 2006). Menurut Mc. Donald yang dikutip oleh Sardiman, prestasi akademik mempunyai tiga unsur penting, yaitu :

1. Prestasi akademik mengawali terjadinya perubahan energy pada diri setiap individu manusia. Perubahan energy yang dimaksud penulis adalah adanya tindakan atau perbuatan yang dilakukan

2. Prestasi akademik ditandai dengan munculnya rasa, afeksi seseorang. Seseorang yang dalam belajarnya mempunyai prestasi akademik tinggi

3. Prestasi akademik dirangsang karena ada tujuan

Prestasi akademik dapat diklasifikasikan menjadi dua yaitu (1) prestasi akademik intrinsik, yaitu prestasi akademik internal yang timbul dalam diri pribadi seseorang itu sendiri, seperti sistem nilai yang dianut, harapan, minat, cita-cita dan aspek lain yang secara internal melekat pada seseorang. Jika dilihat dari segi tujuan kegiatan yang dilakukannya (kegiatan belajar), maka yang dimaksud dengan prestasi akademik intrinsik adalah ingin mencapai tujuan yang terkandung didalam perbuatan belajar itu sendiri.Prestasi akademik intrinsik dapat juga dikatakan sebagai bentuk prestasi akademik yang didalamnya aktivitas belajarnya dimulai dan diteruskan berdasarkan suatu dorongan dari dalam diri dan secara mutlak berkait dengan aktivitas belajarnya.Mahasiswa yang memiliki prestasi akademik intrinsik akan memiliki tujuan menjadi orang yang terdidik, 
yang berpengetahuan, yang ahli dalam bidang studi tertentu; (2) prestasi akademik ekstrinsik, yaitu prestasi akademik eksternal yang muncul dari luar diri pribadi seseorang, seperti kondisi lingkungan kelas, adanya reward bahkan merasa takut oleh hukuman (punishment) merupakan salah satu faktor yang mempengaruhi prestasi akademik. Prestasi akademik instrinsik dapat juga dikatakan sebagai bentuk prestasi akademik yang didalamnya aktivitas belajar dimulai dan diteruskan berdasarkan dorongan dari luar yang tidak secara mutlak berkaitan dengan aktivitas belajar. Kemungkinan besar keadaan siswa itu dinamis, berubah-ubah dan juga mungkin komponen-komponen lain dalam proses belajar mengajar ada yang kurang menarik bagi siswa, sehingga diperlukan prestasi akademik ekstrinsik(Nasution, 2002).

Faktor-faktor yang berperan terhadap prestasi akademik belajar :Cita-cita menurut Hurlock (1979), mengartikan cita-cita sebagai keinginan meraih sesuatu yang lebih tinggi dari keadaan sekarang.Faktor-faktor yang mempengaruhi tingkat cita-cita, Hurlock (1979) mengatakan, kekuatan cita-cita dipengaruhi oleh realita yaitu bagaimana seseorang itu menetapkan cita-caitanya berdasarkan pada realita yang ada.Kemampuan belajar, kemampuan dan kecakapan setiap individu akan memperkuat adanya prestasi akademik.Kondisi jasmani dan rohani mahasiswa, apabila kondisi sehat maka prestasi akademik mahasiswa akan bertambah dan prestasinya akan meningkat Kondisi lingkungan kelasLingkungan turut mempengaruhi tingkat keberhasilan belajar mahasiswa.Slameto (2013:64) menerangkan bahwa faktor yang mempengaruhi belajar mencakup metode mengajar, kurikulum, relasi guru dengan siswa, relasi siswa dengan siswa, disiplin sekolah, alat pelajaran, waktu sekolah, standar pelajaran diatas ukuran, keadaan gedung, metode belajar, dan tugas rumah.Unsur-unsur dinamis belajar.

Dinamis artinya seorang individu dapat menyesuaikan diri dengan lingkungan sekitar. Menurut Winkel (2006), faktor dari dalam diri mahasiswa yang dapat berpengaruh terhadap prestasi akademik antara lain meliputi: pertama, minat dapat mempengaruhi prestasi akademik dan pencapaian hasil belajar; kedua, rasa ingin tahu yang tinggi akan meningkatkan prestasi akademik belajar seorang individu; ketiga, keinginan melaksanakan sesuatu dengan sukses dan sebaik-baiknya; keempat, keinginan untuk melaksanakan tugas, tujuan dan harapan belajar. Sedangkan faktor dari luar yang mempengaruhi prestasi akademik ditimbulkan oleh: pertama, keluarga, berupa pemberian penghargaan; kedua, lingkungan, kondisi lingkungan merupakan suatu unsur-unsur yang datang dari luar diri individu.Upaya dosen dalam membelajarkan mahasiswaPengertian upaya guru adalah usaha yang harus dilakukan oleh guru agarsiswa itu menjadi pribadi yang disiplin.Sebelum mengetahui tentang upaya guru dalam menumbuhkan kedisiplinan siswa. Guru harus mengetahiu pribadi siswa, dimana siswa sebagai peserta didik merupakan salah satu input yang ikut menentukan keberhasilan proses pendidikan

\begin{abstract}
Mahasiswa Tingkat III di pendidikan vokasional DIII keperawatan merupakan mahasiswa tingkat akhir yang siap bekerja di lahan praktek seperti rumah sakit, komunitas dan perusahaan yang harus memiliki kompetensi dalam bidan kognitif, psikomotor dan afektif dalam melayani pasien, keluarga dan masyarakat sehingga dituntut untuk memiliki prestasi akademik yang baik.
\end{abstract}

\section{METODOLOGI}

Penelitian ini dilakukan dengan pendekatan kuantitatif desain cross sectional. Tehnik pengambilan sampel berjumlah 25 responden dengan menggunakan random sampling. Instrumen yang digunakan dengan menggunakan kuesioner yang disusun berdasarkan literatur dengan melihat data dari mahasiswa Akper Manggala Husada Tingkat 3 tentang faktor-faktor yang berperan terhadap prestasi akademik mahasiswa tingkat 3 di Akademi Keperawatan Manggala Husada Jakarta, sehingga diperlukan alat ukur yang valid atau sahih. Instrumen ini termasuk 
penilaian skala likert. kuesioner A berisi karakteristik mahasiswa, kuesioner $\mathrm{B}$ berisi faktor-faktor yang berperan terhadap mahasiswa, kuesioner $\mathrm{C}$ berisi prestasi akademik mahasiswa. Data diolah berdasarkan Analisis Univariat Masingmasing variabel independen, dependen dan confounding dideskripsikan berdasarkan jenis data variabel. Pada penelitian ini untuk variabel independen yaitu cita-cita, kemampuan belajar, kondisi jasmani dan rohani mahasiswa, kondisi lingkungan kelas, unsur-unsur dinamis belajar, upaya dosen dalam membelajarkan mahasiswa. Variabel dependen yaitu prestasi akademik mahasiswa tingkat 3 di Akper Manggala Husada Jakarta. Analisa yang digunakan dalam penelitian ini menggunakan Chi-Squaer untuk mengetahui apakah faktor-faktor yang berperan terhadap prestasi akademik mahasiswa tingkat 3 di Akper Manggala Husada Jakarta.

\section{HASIL PEMBAHASAN}

Analisis Univariat

Karakteristik responden

Jenis kelamin, usia, dan tingkat kelas

Distribusi responden berdasarkan kategori jenis kelamin, usia, dan tingkat dapat dilihat pada tabel 4.1 sebagai berikut:

\section{Tabel 1}

Distribusi Responden Berdasarkan Jenis kelamin, usia dan tingkat kelas Di Akper Manggala Husada Jakarta Tahun $2016(n=25)$

\begin{tabular}{|c|c|c|}
\hline Variabel & Jumlah & Persentase (\%) \\
\hline \multicolumn{3}{|l|}{ Jenis kelamin } \\
\hline Perempuan & 15 & 60 \\
\hline Laki-laki & 10 & 40 \\
\hline \multicolumn{3}{|l|}{ Usia } \\
\hline 21-25 tahun & 23 & 92 \\
\hline Lebih dari 25 tahun & 2 & 0.8 \\
\hline
\end{tabular}

Pada Tabel 1 menunjukkan bahwa dari responden didapatkan proporsi terbesar pada jenis kelamin perempuan sebanyak responden (60\%). Proporsi terbesar berusia 15-20 tahun sebanyak responden (92\%).

Faktor-faktor yang berperan mempengaruhi terhadap peningkatan prestasi belajar mahasiswa di Akper Manggala Husada Jakarta berdasarkan cita-cita, kemampuan belajar, kondisi jasmani dan rohani mahasiswa, kondisi lingkungan kelas, unsurunsur dinamis belajar, upaya dosen dalam membelajarkan mahasiswa dapat dilihat pada tabel .2 sebagai berikut: 
Tabel 2

Distribusi Responden Berdasarkan cita-cita, kemampuan belajar, kondisi jasmani dan rohani mahasiswa, kondisi lingkungan kelas, unsur-unsur dinamis belajar, upaya dosen dalam membelajarkan mahasiswa di Akper Manggala Husada Jakarta Tahun 2016 (n=25)

\begin{tabular}{|c|c|c|}
\hline Variabel & Jumlah & Persentase (\%) \\
\hline \multicolumn{3}{|l|}{ Cita-cita } \\
\hline \multicolumn{3}{|l|}{ Tidak mempengaruhi } \\
\hline Prestasi akademik & 3 & 12 \\
\hline Mempengaruhi prestasi & 22 & 88 \\
\hline \multicolumn{3}{|l|}{ Kemampuan belajar } \\
\hline Tidak mempengaruhi prestasi & 16 & 64 \\
\hline Mempengaruhi prestasi & 9 & 36 \\
\hline \multicolumn{3}{|c|}{ Kondisi jasmani dan rohani mahasiswa } \\
\hline Tidak mempengaruhi prestasi & 14 & 56 \\
\hline Mempengaruhi prestasi & 11 & 44 \\
\hline \multicolumn{3}{|l|}{ Kondisi lingkungan kelas } \\
\hline Tidak mempengaruhi prestasi & 12 & 48 \\
\hline Mempengaruhi prestasi & 13 & 62 \\
\hline \multicolumn{3}{|l|}{ Unsur-unsur dinamis belajar } \\
\hline Tidak mempengaruhi prestasi & 20 & 80 \\
\hline Mempengaruhi prestasi & 5 & 20 \\
\hline \multicolumn{3}{|l|}{$\begin{array}{l}\text { Upaya dosen dalam membelajarkan } \\
\text { mahasiswa }\end{array}$} \\
\hline Tidak mempengaruhi prestasi & 11 & 44 \\
\hline Mempengaruhi prestasi & 14 & 56 \\
\hline \multicolumn{3}{|l|}{ Prestasi akademik belajar } \\
\hline Tidak ada prestasi & 4 & 16 \\
\hline Ada prestasi & 21 & 84 \\
\hline
\end{tabular}

Pada tabel 2 menunjukkan bahwa dari 25 responden didapatkan proporsi terbesar cita-cita mempengaruhi prestasi akademik sebanyak 22 responden (88\%). Proporsi terbesar kemampuan belajar tidak mempengaruhi prestasi akademik sebanyak 16 responden(64\%). Proporsi terbesar kondisi jasmani dan rohani mahasiswa tidak mempengaruhi prestasi akademik sebanyak 14 respoden (56\%). Proporsi terbesar kondisi lingkungan kelas mempengaruhi prestasi akademik belajar sebanyak 13 responden (62\%). Proporsi terbesar unsur-unsur dinamis belajar tidak mempengaruhi prestasi akademik sebanyak 20 responden (80\%). Proporsi terbesar Upaya dosen dalam membelajarkan mahasiswa mempengaruhi prestasi akademik sebanyak 14 responden (56\%). Dan proporsi terbesar adanya prestasi akademik belajar sebanyak 21 responden (84\%)

\section{Analisa Bivariat}

Hubungan cita-cita dengan prestasi akademik belajar mahasiswa di Akper Manggala Husada Jakarta 
Tabel 3

Hubungan cita-cita dengan prestasi akademik belajar mahasiswa di Akper Manggala Husada Jakarta Tahun $2016(n=25)$

\begin{tabular}{|c|c|c|c|c|c|}
\hline \multirow[t]{3}{*}{$\begin{array}{c}\text { Variabel } \\
\text { Independen }\end{array}$} & \multicolumn{2}{|c|}{$\begin{array}{l}\text { Peningkatan prestasi } \\
\text { mahasiswa }\end{array}$} & \multirow[t]{2}{*}{ Total } & \multirow[t]{3}{*}{$\begin{array}{c}\text { OR } \\
95 \% \mathrm{CI}\end{array}$} & \multirow[t]{3}{*}{ P value } \\
\hline & $\begin{array}{c}\text { Tidak ada } \\
\text { peningkatan } \\
\text { prestasi }\end{array}$ & $\begin{array}{c}\text { Ada } \\
\text { peningkatan } \\
\text { prestasi }\end{array}$ & & & \\
\hline & $\%$ & $\%$ & $\mathbf{N}$ & & \\
\hline
\end{tabular}

Cita-cita:

Tidak

$\begin{array}{lllllllll}\begin{array}{l}\text { mempengaruhi } \\ \text { prestasi }\end{array} & 1 & 33.3 & 2 & 66.6 & 3 & 100 & \begin{array}{r}1,187 \\ (0,311-\end{array} & 0,000\end{array}$

akademik

$\begin{array}{llllll}3 & 13.6 & 19 & 86.3 & 22 & 100\end{array}$

Mempengaruhi

prestasi

akademik

$\begin{array}{lllllll}\text { Jumlah } & 4 & 46.9 & 21 & 152 & 25 & 100\end{array}$

Berdasarkan hasil uji statistik pada tabel 3 diperoleh bahwa dari 4 responden yang citacita tidak mempengaruhi prestasi akademik dan tidak memiliki prestasi akademik belajar berjumlah 1 responden $(3.33 \%)$, sedangkan cita-cita tidak mempengaruhi prestasi akademik tetapi ada prestasi akademik belajar berjumlah 2 responden $(66,6 \%)$. Dari 25 responden yang cita-cita mempengaruhi prestasi akademik dan tidak ada prestasi akademik belajar berjumlah 3 responden (13,6\%), sedangkan cita-cita yang mempengaruhi prestasi akademik dan ada prestasi akademik berjumlah 19 responden (86,3\%). Didapatkan nilai $P=0,000$ maka dapat disimpulkan ada hubungan yang signifikan antara cita-cita terhadap prestasi akademik belajar mahasiswa. Hasil analisis juga diperoleh nilai OR (Odd Ratio) $=$ 1,187(95\% CI. 0,311-4,531) artinya cita-cita mempengaruhi prestasi akademik berpeluang 1,187 kali.

Hubungan kemampuan belajar dengan prestasi akademik belajar mahasiswa di Akper Manggala Husada Jakarta 


\section{Tabel 4}

Hubungan kemampuan belajar dengan prestasi akademik belajar mahasiswaTingkat III dI Akper Manggala Husada Jakarta Tahun 2016 (n=25)

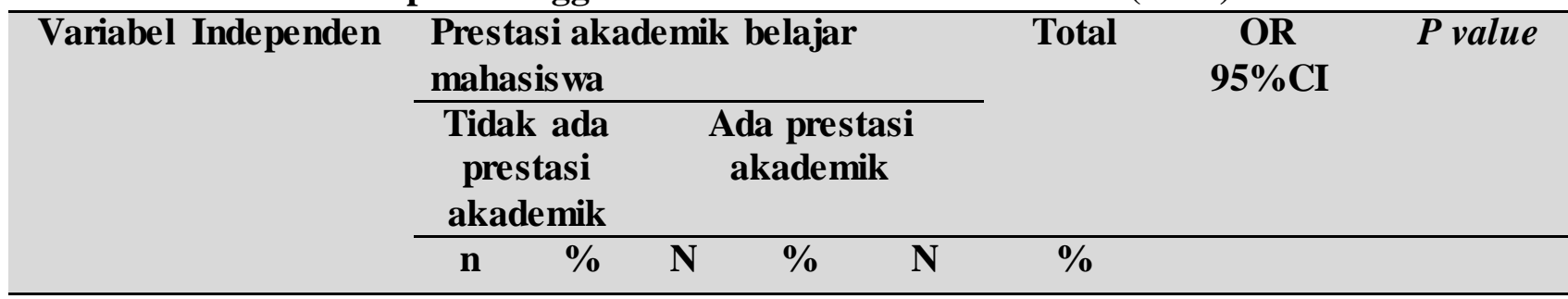

Kemampuan belajar:

Tidak mempengaruhi

prestasi akademik

$4 \quad 18,2 \quad 18 \quad 81,8 \quad 22$

100

0,952

0,000

$(0,385-$

Mempengaruhi prestasi

$2,356)$

akademik

Jumlah

$\begin{array}{llll}1 & 33.3 & 2 & 66.6\end{array}$

$\begin{array}{llll}6 & 51.5 & 24 & 148.4\end{array}$

Berdasarkan hasil uji statistik pada tabel 4 diperoleh bahwa dari 22 responden yang kemampuan belajar tidak mempengaruhi prestasi akademik dan tidak memiliki prestasi akademik belajar berjumlah 4 responden $(18,2 \%)$, sedangkan kemampuan belajar tidak mempengaruhi prestasi akademik tetapi ada prestasi akademik belajar berjumlah 18 responden $(81,8 \%)$. Dari 22 responden yang kemampuan belajar mempengaruhi prestasi akademik dan tidak ada prestasi akademik belajar berjumlah 1 responden $(33,3 \%)$, sedangkan kemampuan belajar mempengaruhi

Tabel 5

Hubungan kondisi jasmani dengan prestasi akademik belajar mahasiswa di Akper Manggala Husada Jakarta

Tahun $2016(\mathbf{n = 2 5})$

\begin{tabular}{|c|c|c|c|c|c|c|c|c|}
\hline \multirow[t]{3}{*}{$\begin{array}{c}\text { Variabel } \\
\text { Independen }\end{array}$} & \multicolumn{4}{|c|}{$\begin{array}{l}\text { Prestasi akademik belajar } \\
\text { mahasis wa }\end{array}$} & \multicolumn{2}{|c|}{ Total } & \multirow[t]{3}{*}{$\begin{array}{c}\text { OR } \\
95 \% \mathrm{CI}\end{array}$} & \multirow[t]{3}{*}{ P value } \\
\hline & \multicolumn{2}{|c|}{$\begin{array}{c}\text { Tidak ada } \\
\text { prestasi } \\
\text { akademik }\end{array}$} & \multicolumn{2}{|c|}{$\begin{array}{c}\text { Ada prestasi } \\
\text { akademik }\end{array}$} & & & & \\
\hline & $\mathbf{n}$ & $\%$ & $\mathbf{N}$ & $\%$ & $\mathbf{N}$ & $\%$ & & \\
\hline $\begin{array}{l}\text { Kondisi } \\
\text { jasmani: }\end{array}$ & & & & & & & & \\
\hline $\begin{array}{l}\text { Tidak } \\
\text { mempengaruhi } \\
\text { prestasi }\end{array}$ & 3 & 20 & 12 & 80 & 15 & 100 & $\begin{array}{c}1,903 \\
(0,758- \\
4,778)\end{array}$ & 0,186 \\
\hline akademik & 2 & 20 & 8 & 80 & 10 & 100 & & \\
\hline $\begin{array}{l}\text { Mempengaruhi } \\
\text { prestasi } \\
\text { akademik }\end{array}$ & & & & & & & & \\
\hline Jumlah & 5 & 40 & 20 & 160 & 25 & 100 & & \\
\hline
\end{tabular}


Berdasarkan hasil uji statistik pada tabel 4 diperoleh bahwa dari 15 responden yang kondisi jasmani tidak mempengaruhi prestasi akademik dan tidak memiliki prestasi akademik belajar berjumlah 3 responden (20\%), sedangkan kondisi jasmani tidak mempengaruhi prestasi akademik tetapi ada prestasi akademik belajar berjumlah 12 responden $(80 \%)$. Dari 10 responden yang kondisi jasmani mempengaruhi prestasi akademik dan tidak ada prestasi akademik belajar berjumlah 2 responden (20\%), sedangkan kondisi jasmani mempengaruhi prestasi akademik dan ada prestasi akademik berjumlah 8 responden (80\%). Didapatkan nilai $P=0,186$ maka dapat disimpulkan tidak ada hubungan yang signifikan antara kondisi jasmani terhadap prestasi akademik belajar mahasiswa. (pvalue >0,05).

Hubungan lingkungan kelas dengan prestasi akademik belajar mahasiswa di Akper Manggala Husada Jakarta

Tabel 6

Hubungan lingkungan kelas dengan prestasi akademik belajar mahasiswa di Akper Manggala Husada Jakarta

Tahun $2016(n=25)$

\begin{tabular}{|c|c|c|c|c|c|c|c|c|}
\hline \multirow[t]{3}{*}{$\begin{array}{c}\text { Variabel } \\
\text { Independen }\end{array}$} & \multicolumn{4}{|c|}{$\begin{array}{l}\text { Prestasi akademik belajar } \\
\text { mahasiswa }\end{array}$} & & \multirow[t]{2}{*}{ Total } & \multirow[t]{3}{*}{$\begin{array}{c}\text { OR } \\
95 \% \mathrm{CI}\end{array}$} & \multirow[t]{3}{*}{ P value } \\
\hline & \multicolumn{2}{|c|}{$\begin{array}{c}\text { Tidak ada } \\
\text { prestasi } \\
\text { akademik }\end{array}$} & \multicolumn{2}{|c|}{$\begin{array}{c}\text { Ada prestasi } \\
\text { akademik }\end{array}$} & & & & \\
\hline & $\bar{n}$ & $\%$ & $\mathbf{N}$ & $\%$ & $\mathbf{N}$ & $\%$ & & \\
\hline $\begin{array}{l}\text { Lingkungan kelas: } \\
\text { Tidak } \\
\text { mempengaruhi } \\
\text { prestasi akademik }\end{array}$ & 5 & 38.5 & 8 & 61.5 & 13 & 100 & $\begin{array}{c}2,450 \\
(1,004-5,978)\end{array}$ & 0,067 \\
\hline $\begin{array}{l}\text { Mempengaruhi } \\
\text { prestasi akademik }\end{array}$ & 3 & 25 & 9 & 75 & 12 & 100 & & \\
\hline Jumlah & 8 & 63.5 & 17 & 136.5 & 25 & 100 & & \\
\hline
\end{tabular}

Berdasarkan hasil uji statistik pada tabel 4 diperoleh bahwa dari 13 responden yang lingkungan kelas tidak mempengaruhi prestasi akademik dan tidak memiliki prestasi akademik belajar berjumlah 5 responden (38.5\%), sedangkan lingkungan kelas tidak mempengaruhi prestasi akademik tetapi ada prestasi akademik belajar berjumlah 8 responden $(61.5 \%)$. Dari 12 responden yang lingkungan kelas mempengaruhi prestasi akademik dan tidak ada prestasi akademik belajar berjumlah 3 responden (25\%), sedangkan lingkungan kelas mempengaruhi prestasi akademik dan ada prestasi akademik berjumlah 9 responden (75\%). Didapatkan nilai $P=0,067$ maka dapat disimpulkan tidak ada hubungan yang signifikan antara lingkungan kelas terhadap prestasi akademik belajar mahasiswa. (pvalue $>0,05$ ).

Hubungan lingkungan kelas dengan prestasi akademik belajar mahasiswa di Akper Manggala Husada Jakarta 
Tabel 7

Hubungan unsur-unsur dinamis dengan prestasi akademik belajar mahasiswa Tingkat 3 di Akper Manggala Husada Jakarta

Tahun $2016(\mathbf{n}=25)$

\begin{tabular}{|c|c|c|c|c|c|c|c|c|}
\hline \multirow[t]{3}{*}{ Variabel Independen } & \multicolumn{4}{|c|}{$\begin{array}{l}\text { Prestasi akademik } \\
\text { belajar mahasiswa }\end{array}$} & \multirow{2}{*}{\multicolumn{2}{|c|}{ Total }} & \multirow[t]{3}{*}{$\begin{array}{c}\text { OR } \\
95 \% \mathrm{CI}\end{array}$} & \multirow[t]{3}{*}{ P value } \\
\hline & \multicolumn{2}{|c|}{$\begin{array}{c}\text { Tidak } \\
\text { ada } \\
\text { prestasi } \\
\text { akademik }\end{array}$} & \multicolumn{2}{|c|}{$\begin{array}{c}\text { Ada } \\
\text { prestasi } \\
\text { akademik }\end{array}$} & & & & \\
\hline & $\mathbf{n}$ & $\%$ & $\mathbf{N}$ & $\%$ & $\mathbf{N}$ & $\%$ & & \\
\hline $\begin{array}{l}\text { Unsur-unsur dinamis : } \\
\text { Tidak mempengaruhi } \\
\text { prestasi akademik }\end{array}$ & 3 & 25 & 9 & 75 & 12 & 100 & $\begin{array}{r}3,467 \\
(0,769-\end{array}$ & 0,106 \\
\hline $\begin{array}{l}\text { Mempengaruhi prestasi } \\
\text { akademik }\end{array}$ & 1 & 7.69 & 12 & 92.3 & 13 & 100 & $15,641)$ & \\
\hline Jumlah & 4 & 32.7 & 21 & 167.3 & 25 & 100 & & \\
\hline
\end{tabular}

Berdasarkan hasil uji statistik pada tabel 7 diperoleh bahwa dari 12 responden yang unsur-unsur dinamis tidak mempengaruhi prestasi akademik dan tidak memiliki prestasi akademik belajar berjumlah 3 responden (25\%), sedangkan unsur-unsur dinamis tidak mempengaruhi prestasi akademik tetapi ada prestasi akademik belajar berjumlah 9 responden $(75 \%)$. Dari 13 responden yang unsur-unsur dinamis mempengaruhi prestasi akademik dan tidak ada prestasi akademik belajar berjumlah 1 responden (7.69\%), sedangkan unsur-unsur dinamis mempengaruhi prestasi akademik dan ada prestasi akademik berjumlah 12 responden (92,3\%). Didapatkan nilai $P=0,106$ maka dapat disimpulkan tidak ada hubungan yang signifikan antara unsur-unsur dinamis terhadap prestasi akademik belajar mahasiswa. (pvalue >0,05).

Hubungan upaya dosen dengan prestasi akademik belajar mahasiswa di Akper Manggala Husada Jakarta

\section{Tabel 8}

Hubungan upaya dosen dengan prestasi akademik belajar mahasis wa di Akper Manggala Husada Jakarta Tahun $2016(\mathbf{n}=\mathbf{2 5})$

\begin{tabular}{|c|c|c|c|c|c|c|c|c|}
\hline \multirow[t]{3}{*}{ Variabel Independen } & \multicolumn{4}{|c|}{$\begin{array}{l}\text { Prestasi akademik } \\
\text { belajar mahasiswa }\end{array}$} & \multirow{2}{*}{\multicolumn{2}{|c|}{ Total }} & \multirow[t]{3}{*}{$\begin{array}{c}\text { OR } \\
95 \% \mathrm{CI}\end{array}$} & \multirow[t]{3}{*}{$\begin{array}{c}P \\
\text { value }\end{array}$} \\
\hline & \multicolumn{2}{|c|}{$\begin{array}{c}\text { Tidak } \\
\text { ada } \\
\text { prestasi } \\
\text { akademik } \\
\end{array}$} & \multicolumn{2}{|c|}{$\begin{array}{c}\text { Ada } \\
\text { prestasi } \\
\text { akademik }\end{array}$} & & & & \\
\hline & $n$ & $\%$ & $\mathbf{N}$ & $\%$ & $\mathbf{N}$ & $\%$ & & \\
\hline Upaya dosen : & & & & & & & & \\
\hline $\begin{array}{l}\text { Tidak mempengaruhi prestasi } \\
\text { akademik }\end{array}$ & 1 & 8.33 & 11 & 91.6 & 12 & 100 & $\begin{array}{c}0,428 \\
(0,159-\end{array}$ & 0,112 \\
\hline Mempengaruhi prestasi & & & & & & & $1,152)$ & \\
\hline akademik & 3 & 23 & 10 & 76.92 & 13 & 100 & & \\
\hline Jumlah & 4 & 31.3 & 21 & 168.5 & 25 & 100 & & \\
\hline
\end{tabular}


Berdasarkan hasil uji statistik pada tabel 8 diperoleh bahwa dari 12 responden yang upaya dosen tidak mempengaruhi prestasi akademik dan tidak memiliki prestasi akademik belajar berjumlah 1 responden $(8.33 \%)$, sedangkan upaya dosen tidak mempengaruhi prestasi akademik tetapi ada prestasi akademik belajar berjumlah 11 responden $(91.6 \%)$. Dari 13 responden yang upaya dosen mempengaruhi prestasi akademik dan tidak ada prestasi akademik belajar berjumlah 3 responden (23\%), sedangkan upaya dosen mempengaruhi prestasi akademik dan ada prestasi akademik berjumlah 10 responden (76,92\%). Didapatkan nilai $P=0,112$ maka dapat disimpulkan tidak ada hubungan yang signifikan antara upaya dosen terhadap prestasi akademik belajar mahasiswa. (pvalue $>0,05)$.

Hubungan jenis kelamin dengan prestasi akademik belajar mahasiswa di Akper Manggala Husada Jakarta

Tabel 9

Hubungan jenis kelamin dengan prestasi akademik belajar mahasiswa di Akper Manggala Husada Jakarta

Tahun $2016(n=25)$

\begin{tabular}{|c|c|c|c|c|c|c|c|c|}
\hline \multirow[t]{3}{*}{ Variabel Independen } & \multicolumn{4}{|c|}{$\begin{array}{l}\text { Prestasi akademik } \\
\text { belajar mahasiswa }\end{array}$} & \multirow{2}{*}{\multicolumn{2}{|c|}{ Total }} & \multirow[t]{3}{*}{$\begin{array}{c}\text { OR } \\
95 \% \mathrm{CI}\end{array}$} & \multirow[t]{3}{*}{$\begin{array}{c}P \\
\text { value }\end{array}$} \\
\hline & \multicolumn{2}{|c|}{$\begin{array}{c}\text { Tidak } \\
\text { ada } \\
\text { prestasi } \\
\text { akademik }\end{array}$} & \multicolumn{2}{|c|}{$\begin{array}{c}\text { Ada } \\
\text { prestasi } \\
\text { akademik }\end{array}$} & & & & \\
\hline & $\mathbf{n}$ & $\%$ & $\mathbf{N}$ & $\%$ & $\mathbf{N}$ & $\%$ & & \\
\hline \multicolumn{9}{|l|}{ Jenis Kelamin: } \\
\hline Laki-laki & 3 & 23 & 10 & 76.9 & 13 & 100 & \multirow{3}{*}{$\begin{array}{c}1,144 \\
(0,350- \\
3,741)\end{array}$} & 0,000 \\
\hline Perempuan & 2 & 16.6 & 10 & 83.3 & 12 & 100 & & \\
\hline Jumlah & 5 & 39.6 & 20 & $\mathbf{1 6 0 . 2}$ & 25 & 100 & & \\
\hline
\end{tabular}

Berdasarkan hasil uji statistik pada tabel 9 diperoleh bahwa dari 13 responden yang jenis kelamin laki-laki sebagian besar tidak tidak ada prestasi akademik belajar berjumlah 3 responden $(23 \%)$ dan yang ada prestasi akademik belajar berjumlah 10 responden (76.9\%). Dari 12 responden yang jenis kelamin perempuan sebagian besar tidak ada prestasi akademik belajar berjumlah 2 responden $(16,6 \%)$ dan yang ada prestasi akademik belajar berjumlah 10 responden (83,3\%). Didapatkan nilai $P=0,000$ maka dapat disimpulkan ada Hubungan yang signifikan antara jenis kelamin terhadap prestasi akademik belajar. Hasil analisis juga diperoleh nilai OR (Odd Ratio) $=1,144(95 \%$ CI. 0,350-3,741). Artinya jenis kelamin mempengaruhi prestasi akademik berpeluang 1,144 kali

Hubungan usia dengan prestasi akademik belajar mahasiswa di Akper Manggala Husada Jakarta 
Tabel 10 Hubungan usia dengan prestasi akademik belajar mahasis wa di Akper Manggala Husada Jakarta Tahun 2016 (n=25)

\begin{tabular}{|c|c|c|c|c|c|}
\hline \multirow[t]{3}{*}{ Variabel Independen } & \multicolumn{2}{|c|}{$\begin{array}{l}\text { Prestasi akademik } \\
\text { belajar mahasiswa }\end{array}$} & \multirow[t]{2}{*}{ Total } & \multirow[t]{3}{*}{$\begin{array}{c}\text { OR } \\
95 \% \mathrm{CI}\end{array}$} & \multirow[t]{3}{*}{$\begin{array}{c}P \\
\text { value }\end{array}$} \\
\hline & $\begin{array}{c}\text { Tidak } \\
\text { ada } \\
\text { prestasi } \\
\text { akademik }\end{array}$ & $\begin{array}{c}\text { Ada } \\
\text { prestasi } \\
\text { akademik }\end{array}$ & & & \\
\hline & $\mathrm{N} \%$ & $\%$ & $\mathbf{N}$ & & \\
\hline
\end{tabular}

Usia:

\begin{tabular}{rccccccc}
$21-25$ tahun & 3 & 13.6 & 19 & 86.3 & 22 & 100 & 0,796 \\
\multicolumn{2}{r}{25 tahun } & 1 & 33.3 & 2 & 66.6 & 3 & 100 \\
\hline & Jumlah & $\mathbf{4}$ & $\mathbf{4 6 . 9}$ & $\mathbf{2 1}$ & $\mathbf{1 5 2 . 9}$ & $\mathbf{2 5}$ & $\mathbf{1 0 0}$ \\
\hline
\end{tabular}

Berdasarkan hasil uji statistik pada tabel 10 diperoleh bahwa dari 25 responden yang usia 21-25 tahun sebagian besar tidak ada prestasi akademik belajar berjumlah 3 responden $(13,6 \%)$ dan yang ada prestasi akademik belajar berjumlah 19 responden $(86,3 \%)$. Dari 22 responden yang usia 21-25 tahun sebagian besar tidak ada prestasi akademik belajar berjumlah 3 responden $(13,6 \%)$ dan yang ada prestasi akademik belajar berjumlah 19 responden $(86,3 \%)$. Dari 2 reponden yang usia > 25 tahun sebagian besar ada prestasi akademik belajar berjumlah 2 orang $(66.6 \%)$. Didapatkan nilai $P=0,796$ maka dapat disimpulkan tidak ada hubungan yang signifikan antara usia terhadap prestasi akademik belajar mahasiswa (pvalue >0,05).

\section{SIMPULAN}

Berdasarkan hasil penelitian dan pembahasan tentang faktor-faktor yang berperan terhadap peningkatan prestasi belajar mahasiswa di Akademi Keperawatan Manggala Husada Jakarta, dapat disimpulkan sebagai berikut: Hasil penelitian berisikan tentang cita-cita, kemampuan belajar, kondisi jasmani dan rohani mahasiswa, kondisi lingkungan kelas, unsur-unsur dinamis belajar, upaya dosen dalam membelajarkan mahasiswa, karakteristik dari 25 responden sebagian besar $(60 \%)$ berjenis kelamin perempuan. Sebagian besar (92\%) responden berusia 15-20 tahun. Faktor yang berpengaruh pada prestasi akademik mahasiswa adalah cita-cita dengan prestasi akademik belajar mahasiswa di Akademi Keperawatan Manggala Husada Jakarta dengan p Value $=0,00$, Nilai $\mathrm{OR}=1,187$ Kali.

Menurut Daruyani, Wilandari, \& Yasin, 2013, prestasi akademik dipengaruruhi oleh beberapa faktor, baik faktor dalam diri mahasiswa (internal) maupun faktor dari luar mahasiswa (eksternal). Beberapa penelitian telah menunjukkan banyak faktor yang mempengaruhi prestasi akademik. Faktor internal antara lain : intelegensi, konsep diri dan lain sebagainya, sedangkan Fakor eksternal antara lain: keluarga, status sosial, lingkungan akademik dan lain sebagainya) (Garkaz, Banimahd, \& Esmaeili, 2011).

Menurut pendapat dari Murphy (2009) yang menyebutkan bahwa faktor yang mempengaruhi prestasi belajar yaitu: "the extent to which educators, students, and the total educational environtment reflect culture competence significantly affects the nature and type of schooling, conditions of learning, as well as learning outcome". Pendapat tersebut mengandung makna bahwa faktorfaktor yang berpengaruh terhadap prestasi belajar diantaranya adalah pendidik, siswa, dan lingkungan pendidikan yang mencerminkan budaya kompetensi. Faktor pendidik dapat dilihat dari kinerja guru, faktor 
mahasiswa dapat dilihat dari motivasi dan disiplin belajar, lingkungan pendidikan dapat dilihat dari sarana dan prasarana sekolah, serta dukungan orang tua.

\section{SARAN}

Bagi Pendidikan Keperawatan : Perlunya komunikasi yang baik antara pembimbing akademik dengan mahasiswa terkait dengan peningkatan prestasi belajar. Meningkatkan kegiatan-kegiatan mahasiswa dengan cara membuat program perencanaan bimbingan antara mahasiswa dan dosen dalam hal pembelajaran dan penugasan sehingga mahasiswa akan memiliki prestasi akademik yang meningkat. Perlunya peningkatan kualitas dalam pengembangan proses pembelajaran belajar mengajar, sarana, prasarana untuk meningkatkan mutu kualitas mahasiswa

\section{DAFTAR PUSTAKA}

Dharma. K.K (2011), Metodologi Penelitian Keperawatan. CV. Trans Info Media : Jakarta

Dimyati dan Mujiono. 2009. Belajar dan Pemberlajaran. Jakarta: Rineka Cipta

Daruyani, S., Wilandari, Y., \& Yasin, H. (2013). Faktor-Fakor Yang Mempengaruhi Indeks Prestasi \begin{tabular}{lll}
\hline Mahasiswa & FSM & Universitas \\
\hline
\end{tabular}

Diponegoro Semester Pertama Dengan Metode Regresi Logistik Biner. Dalam S. Daruyani (Penyunt.), Seminar Nasional Statistika. Semarang, hal. 185 - 193. Universitas Diponegoro.

Firiah. 2010. Kajian empiris atas perilaku belajar dan kecerdasan emosional dalam mempengaruhi stres kuliah mahasiswa akuntansi (Studi Kasus Pada STIENU JEPARA). Skripsi, Sekolah Tinggi Ilmu Ekonomi Nahdlatul Ulama' (STIENU) Jepara.

Gibson, James L, John M. Ivancevich dan james H. Donnelly Jr. 2000. Organizations: Behavioue, Structure and Process. Boston: McGraw-Hill Companies Inc

Hamzah B, Uno.Teori Prestasi akademik dan Pengukurannya. Jakarta: Bumi Aksara, 2008: hal 23

Hastono, S.P. (2007)._. Analisis Data Kesehatan. Jakarta: Fakultas Ilmu Kesehatan Masyarakat Universitas Indonesia

Hurlock, Elizabeth B. 2003. Adolescent Development (Terjemahan). Penerjemah Muslichan Zarkasih. Jakarta: Erlangga

Murphy, P.K. (2009). Cultural competence initiative. The Arlington Publics Schools.

Notoatmojo, S. (2010). Metedologi Penelitian Kesehatan. Jakarta: Rineka Cipta

Pujadi, A. (2007). Faktor-Faktor Yang Mempengaruhi Prestasi akademik Belajar Mahasiswa.Business and Management Journal Bunda Mulia 3(2): 40-51

Peraturan Menteri Riset, Teknologi dan Pendidikan Tinggi Nomor 44 Tahun 2015 tentang Standar Nasional Pendidikan Tinggi

Sukiniarti (2006).Hubungan Antara Pemahaman Mahasiswa UT Tentang SPJJ dan Prestasi akademik Belajar Dengan Hasil Belajar. Journal Pendidikan 7(1): 12-18

Hakim, Thursan. 2010. Belajar Secara Efektif. $\underline{\text { Jakarta. }}$

Muhibbin Syah, 2010. Psikologi Pendidikan dengan Pendekatan Baru. Bandung: Remaja Rosdakarya

Sardiman, A.M. 2011. Interaksi dan Prestasi akademik Belajar Mengajar. Jakarta: Rajagrafindo

Slameto. 2013. Belajar dan Faktor-faktor yang mempengaruhi. Jakarta: Rineka Cipta 
Suardi, Muhammad. 2015. Belajar dan Pembelajaran. Ed. I. Cet. I. Yogyakarta: Depublish.

Sukmadianata, Nana Syaodih. 2007. Landasan Psikologi Proses Pendidikan. Bandung: Remaja Rosdakarya

Tarmidi. (2006). Iklim kelas dan prestasi belajar. Medan: Fakultas Kedokteran Universitas Sumatera Utara. http $/ /$ library.usu.ac.id/download/fk/060 10310.pdf/ 